\title{
Esclerosis Tuberosa
}

Tuberous Sclerosis

Linda Julissa López Flores, * Héctor Rubén Caballero Castro. **

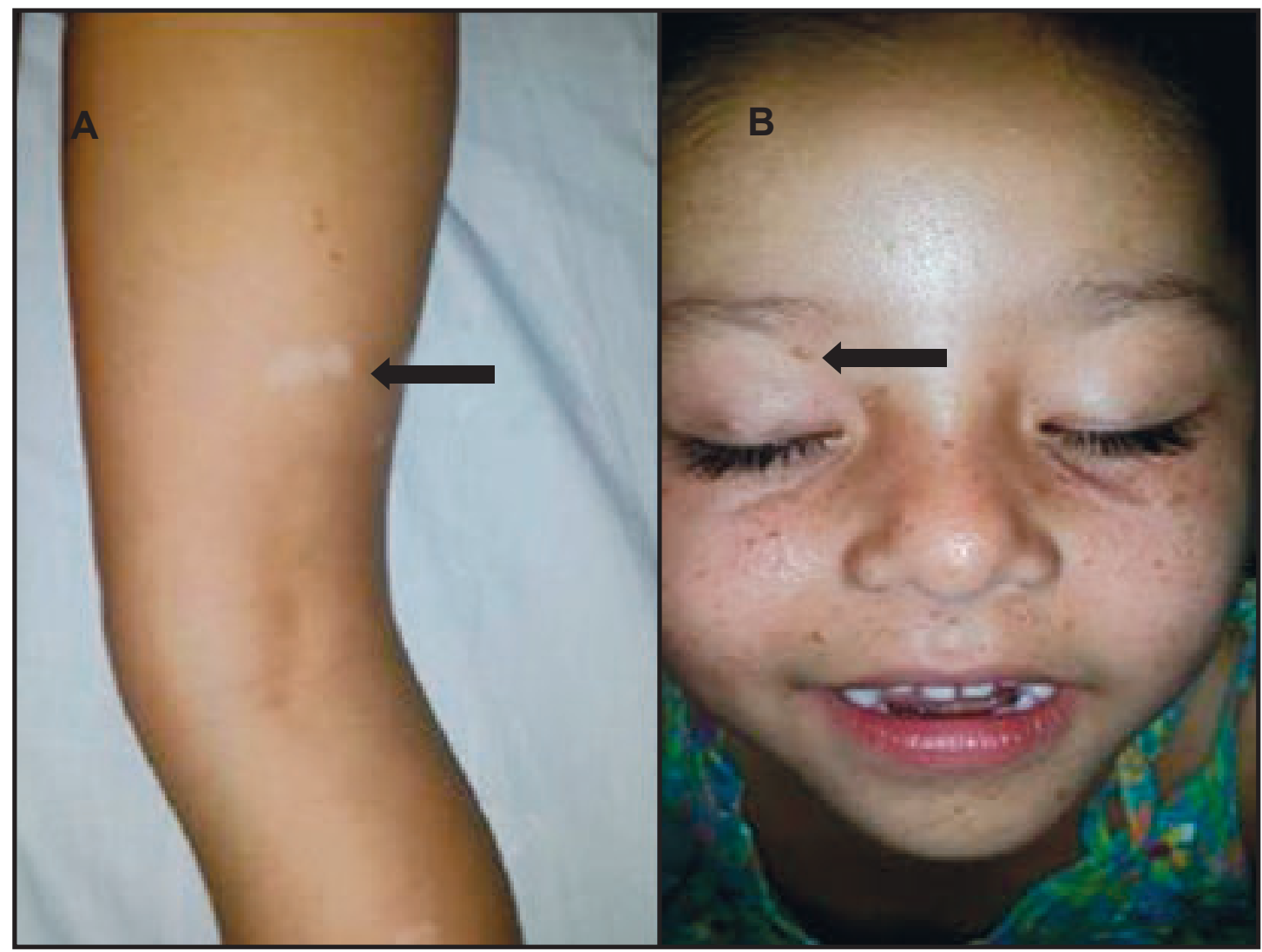

Niña de cinco años cuya madre consulta por haber observado desde su nacimiento máculas hipopigmentadas, distribuidas en tronco y extremidades que son en forma de "hoja de fresno" (A) y que últimamente le preocupan por sospecha de vitíligo. Los angiofibromas (B) en nariz, mejillas y mentón los atribuía a posibles lunares que se caracterizan por aparición progresiva a partir de los 6 años de edad. La paciente nunca presentó manifestaciones neurológicas, pero este hallazgo incidental, ha motivado a realizar más estudios para poder sustentar el diagnóstico de una de las enferme-

\footnotetext{
* Médico Residente de primer año del posgrado de Pediatría. Universidad Nacional Autónoma de Honduras, Valle de Sula, UNAH-VS.

** Dermatólogo Pediatra Instituto Hondureño de Seguridad Social. Dirigir correspondencia a: lindalopezf@hotmail.com

Recibido: 14 de junio 2015 Aprobado: 25 de diciembre 2015
}

dades neurocutáneas más importantes y menos diagnosticada por su rara presentación a tan temprana edad.

El complejo esclerosis tuberosa (CET) constituye un desorden multisistémico hereditario caracterizado por el desarrollo de hamartomas en numerosos órganos. Está presente en $1 / 6000$ nacidos vivos. Se debe a mutaciones espontáneas en los genes TSC1 o TSC2. Las proteínas afectadas se denominan respectivamente, hamartina y tuberina, que actúan como represores tumorales. EI CET tiene una expresión clínica heterogénea, desde retraso psicomotor grave y epilepsia incapacitante hasta otros en los que el neurodesarrollo es normal y no hay crisis. También puede verse afectado el corazón y los riñones. 